\title{
地質リスクからみた山岳トンネルの地質調査 における留意点
}

\author{
（独）防災科学技術研究所 長谷川信介*1 \\ 京都大学大学院 大津 宏康*2 \\ By Nobusuke HASEGAWA, Hiroyasu OHTSU
}

\begin{abstract}
山岳トンネルにおいては, 調査・設計段階で予測された地山状況と実際の地山状況が 大きく乘離し，施工段階において建設コストの大幅な増加がしばしば発生している．この ような乘離が生じる原因として, 事前調査で得られる地盤情報の不確実性が挙げられる. 著者らは事前調査で得られる地盤情報の不確実性に起因するトンネル掘削コストの変動リ スク（以下, 地質リスク）の評価および施工実績との比較を行ってきた。これまでの研究 では，地質調查で得られる地盤情報の不確実性を考慮したときの乘離量に着目してきた。 しかし, 地質リスクのマネジメントにおいては, 可能性は低いが顕在化すると大きな損失 が生じる事象のマネジメントも重要である，そこで，本論文では，事前調查において予見 されなかった不良地山が出現したため追加調查を実施した事例を用いて, 事前調查および 追加調查における地質リスクと施工実績との比較を行った。事前調査における地質リスク では, 施工実績に示される地山状況が出現する確率は低く, 追加調查により確率は高くな ることを予想した. しかし, 追加調査において地盤情報の不確実性を適切に評価せずに地 盤情報を追加すると，実際の地山状況が出現する確率は事前調査に比べて低くなった。こ のことから, 単純に地質情報が増えることが重要なのではなく, 適切に不確実性が評価さ れた地盤情報が増えることが重要であることがわかった.
\end{abstract}

【キーワード】山岳トンネル, 地質リスク, 地盤情報の不確実性, 地山分類表, コ

ア評価点

\section{1. はじめに}

山岳トンネルにおいては，調査・設計段階で予測 された地山状況と実際の地山状況が大きく乘離し, その結果, 施工段階において建設コストの大幅な増 加が生じる事態がしばしば発生している。このよう なことから，「事前調査結果は当たらない」と言わ れてきた ${ }^{1)}$.しかし，近年では国や地方自治体等の財 政悪化や建設公共投資に対する国民の監視の目が厳 しくなるなか, 施工段階における建設コストの大幅 な増加は認められにくくなってきている．このため, 事前調査においては, 予測された地山状況と実際の 地山状況が大きく乘離しないことが求められるよう になってきている.
このような乘離が生じる要因と対策として, 鈴 木・冨田 ${ }^{2)}$ は, (1)地質調査技術の限界, (2)不十分な地 質調查, (3)事実と解釈の区別, (4)地質解釈は人によ って異なる, (5)残された問題点の成果物への明記を 挙げている. 中川ら ${ }^{33}$ は, 前記(3)〜(5)は地質技術者の 地山解釈に対する個人差と捉え, 「事前調查・設計 段階から施工段階までの異なる技術者間に対する個 人差」もその要因の 1 つとしている.これに対し, 著者らは、事前調査において得られる地盤情報の不

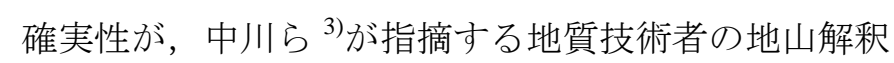
に対する個人差を生じさせると考える.

地盤情報の不確実性が事業に及ぼすリスクを地質 リスクと呼び，そのマネジメントが注目されるよう

*1 社会防災システム研究領域 研究員 029-863-7858, hasegawa-nobusuke@bosai.go.jp

*2 工学研究科 教授 075-383-3260, ohtsu@toshi. kuciv. kyoto-u. ac. jp 
になってきている ${ }^{4)}$.ただ，これまでのところ損失を 生じさせる事象の洗い出しにとどまり，そのような 事象の発生確率の評価までは行われていない。著者 らは，地質リスクに基づきマネジメント（意思決 定）を行うためには，損失が生じる確率を評価する 必要があると考える，そこで，モンテカルロシミュ レーションにより地盤情報の不確実性の確率評価お よび地質リスク評価を試みている ${ }^{5) \sim 8) . な お, こ こ ~}$ で言う地質リスクとは, 地盤情報の不確実性に起因 するトンネル掘削コストの変動リスクとしており, 本論文でもこれに従う。これら一連の研究において は，地質リスク評価手法の開発を目的とし，主に地 盤情報の不確実性を考慮したときの掘削コストと施 工実績との乘離量について検討を行ってきた．ただ， 地質リスクのマネジメントにおいては，乘離量を小 さくすることは重要であるが，可能性は低いが顕在 化すると損失が大きい事象のマネジメントも重要で ある。そこで, 本論文では, 事前調查において予見 されなかった不良地山に遭遇し, 施工段階で追加調 查が実施された事例を用いて地質リスク評価を行う。 このような事例においては，事前調査における地質 リスクでは施工実績で示される実際の地山状況が出 現する確率は低く，追加調查における地質リスクで は確率は高くなることが予想される，そこで，事前 調查および追加調査における地質リスクと施工実績 との比較を行い，これまで開発してきた地質リスク 評価手法の適用性について検討を行う.

\section{2. トンネル地山の事前調査と追加調査の概要}

検討を行ったトンネルは，和歌山県の紀伊半島に 位置する（図一1）。全長は約 $1.7 \mathrm{~km} の 2$ 車線道路卜

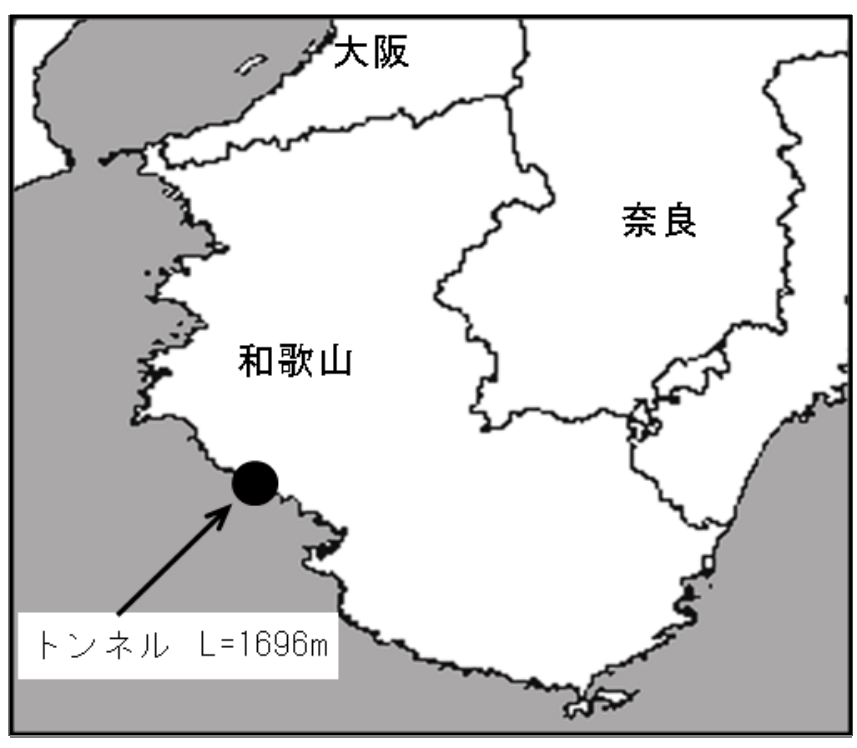

図-1 トンネル位置図

ンネルである。地質は古第三紀の四万十帯音無川層 群で, 亀裂の発達した泥岩層と砂岩・泥岩互層が分 布する。

\section{(1) 事前調査の概要}

事前調查では, 地表地質踏査, 屈折法弾性波探査, 両坑口付近のボーリング調査が実施された。ただ, 事前調查結果をみると, 地山等級は屈折法弾性波探 査結果をもとに地山分類表による区分に従い判定さ れた地山等級にほぼ一致する。このことは, 露頭が ほとんどなく, また, 両坑口を除くとボーリング調 查が実施されていないことから，地山性状に関する 情報がほとんど得られていないため, 弾性波速度を もとに地山評価が行われたと推察される. 図一2 に弾 性波速度分布を示す。屈折法弾性波探査では, 深く

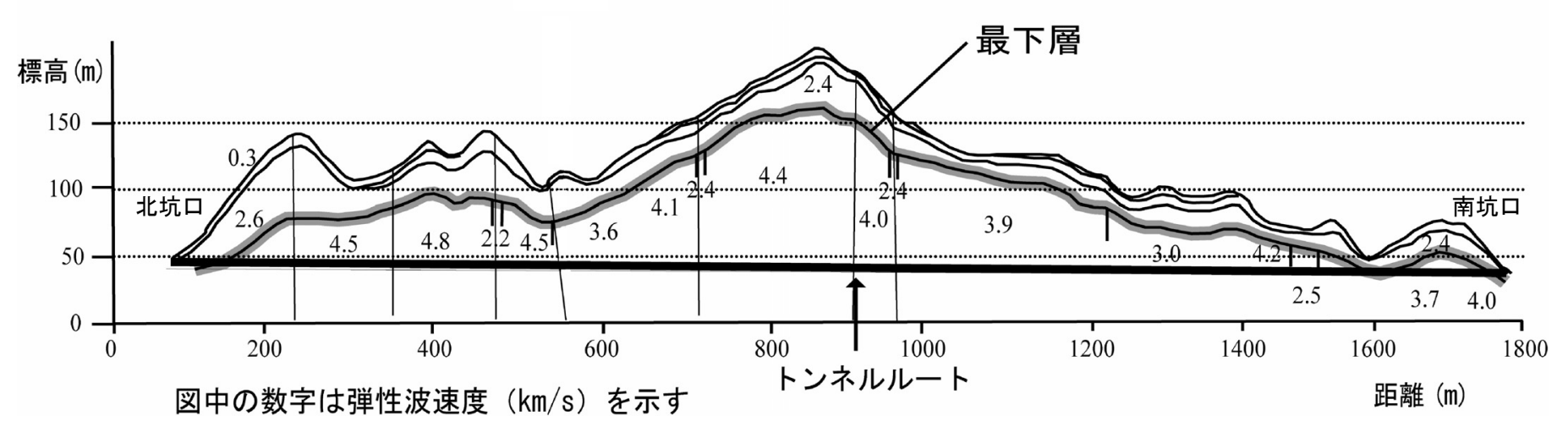

図－2 弾性波速度分布 

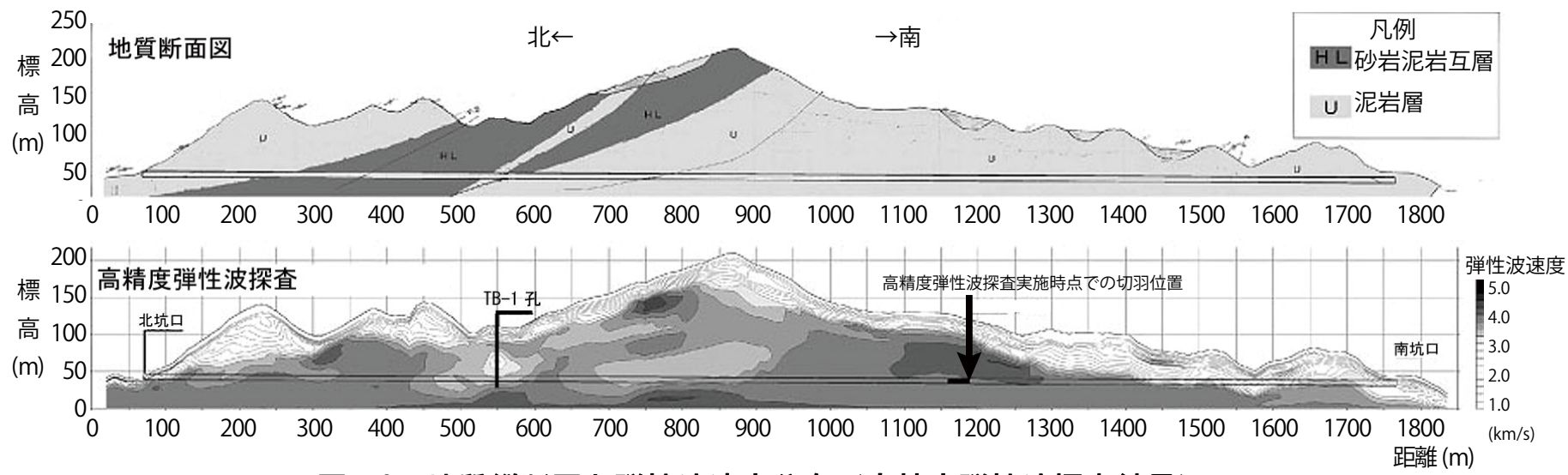

図-3 地質縦断図と弾性波速度分布（高精度弾性波探査結果）

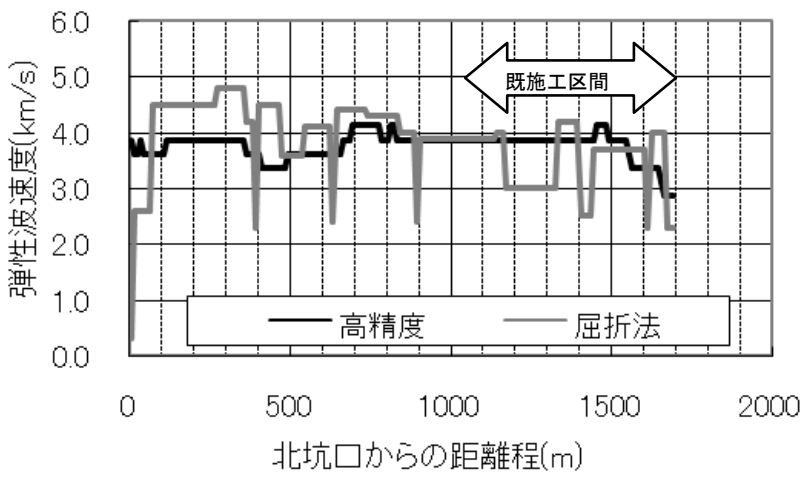

\section{図－4 高精度弾性波探査と屈折法弾性波探査による トンネル掘削位置における弾性波速度の比較}

なるにつれて弾性波速度が速くなることを前提とし て解析が行われる。このため, 屈折法弾性波探查で 得られる最下層以深の弾性波速度については, 実際 には最下層上面の弾性波速度より低速度な速度構造 が存在していても検出することができない。そこで， 最下層上面の弾性波速度が鉛直下方に連続するもの として解釈される。このようなことから, 事前調査 ではトンネル掘削位置における弾性波速度は，概ね $3.0 \sim 4.8 \mathrm{~km} / \mathrm{s}$ と解釈され, 地山等級は C I 地山が主 体と評価されたものと推察される.

\section{(2) 追加調査の概要}

トンネル掘削は, 図一3 に示寸南坑口から進められ た。しかし, 掘削開始直後から D 地山が連続し, 事 前調査結果との乘離が大きいことから，未施工区間 を対象に D 地山の分布を把握することを目的とした 追加調査が実施された。
追加調査では, 屈折法弾性波探査結果における最 下層以深の弾性波速度を把握することを目的として， 図-3 に示寸 TB-1 孔を掘削し，TB-1 孔を利用した高 精度弾性波探査（二次元弾性波卜モグラフィー）が 実施された ${ }^{9)}$. なお， TB-1 孔は孔壁が崩れやすく， トンネル掘削深度付近を除き，孔壁保護のための管 が挿入された。このため, 高精度弾性波探査におい ては，TB-1 孔はトンネル掘削深度付近の裸孔部にお いて受振点として利用された。発破は図ー3に示寸切 羽と北坑口で行われ, 北坑口から切羽直上間の地表 と TB-1 孔に受振器を設置して測定が行われた。こう して得られた測定データと事前調査における屈折法 弾性波探査における測定デー夕をあわせて高精度弾 性波探查の解析が行われた，図ー3に追加調查による 推定地質断面と高精度弾性波探査による弾性波速度 分布を示す。また，図一4 に屈折法弾性波探査と高精 度弾性波探査によるトンネル掘削位置における弾性 波速度を示す。高精度弾性波探査で測定データが増 えたのは北坑口から切羽の間である。この区間にお ける高精度弾性波探査結果では, トンネル掘削位置 における弾性波速度は概ね 3.5 4.2 km/s となってい る. とくに, 北坑口からの距離程 80〜 500m では屈折 法弾性波探査結果より低速度を示す。一方，切羽か ら南坑口の間（既施工区間）は屈折法弾性波探査に おける測定データが高精度弾性波探査の解析に用い られている。屈折法弾性波探査および高精度弾性波 探查とも，トンネル全体の地山を対象に解析が行わ れており，解析手法や解析に用いるデー夕数が異な ることから，屈折法弾性波探査と高精度弾性波探査 では異なる結果になったものと考えられる。 
追加調査では，二次元比抵抗電気探査も実施され， これら調査結果と既施工区間の地山状況をもとに, 未施工区間の地山は D 地山が主体と評価された。な お，施工で明らかとなった地山状況は D 地山が主体 であり，追加調査の結果とほぼ一致した。

\section{3. 事前調査における地質リスクと施エ実績との 比較}

事前調查においては，一般的に地山分類表をもと に, 岩種, 弾性波速度, 地山性状などから地山等級 の判定が行われる. 四万十帯のような付加体地質の 地山では，弾性波速度をもとに地山等級を判定する と実際の地山状況との乘離が大きいことが知られて いる。ただ，本トンネル地山においては，露頭がほ とんどないこと, 両坑口を除きボーリング調査が実 施されていないことから，地山性状に関する情報が ほとんど得られていない。このようなことから，岩 種と弾性波速度により地質リスク評価を行う。岩種 と弾性波速度をもとに地山分類表により地山等級を 判定する場合には，弾性波速度の不確実性と地山分 類表に示される弾性波速度に基づく地山等級の判定 における不確実性を考慮する必要がある. 前述のよ うに，屈折法弾性波探査により得られる弾性波速度 は，解析原理により最下層以深においては最下層上 面の弾性波速度より低速度な速度構造が存在しても 検出することができない。このため, 最下層以深の 弾性波速度は，最下層上面における弾性波速度より 低速度な速度構造が分布すると考える。

地山分類表に示される地山等級と弾性波速度との 関係は, 数々のトンネル地山の弾性波速度を分析し た結果である。したがって，これまでの経験の集積 知である地山分類表の弾性波速度区分を地山の弾性 波速度に関する拘束条件として用いることとする.

図－5に旧）日本道路公団による地山分類表 ${ }^{10)}$ 示す。本トンネル地山の地質は古第三紀泥岩が主体 である. 事前調查においては最下層以深の弾性波速 度構造が不明であることから地質分布も不明である こと,また，地山の地質は主として古第三紀泥岩で あることから，ここでは単純化し，古第三紀泥岩の み分布するとみな寸。古第三紀泥岩は図一 5 に示寸地 山分類表における L 層状第三紀層泥岩に分類される. 前述のように, 最下層以深の弾性波速度は, 最下層

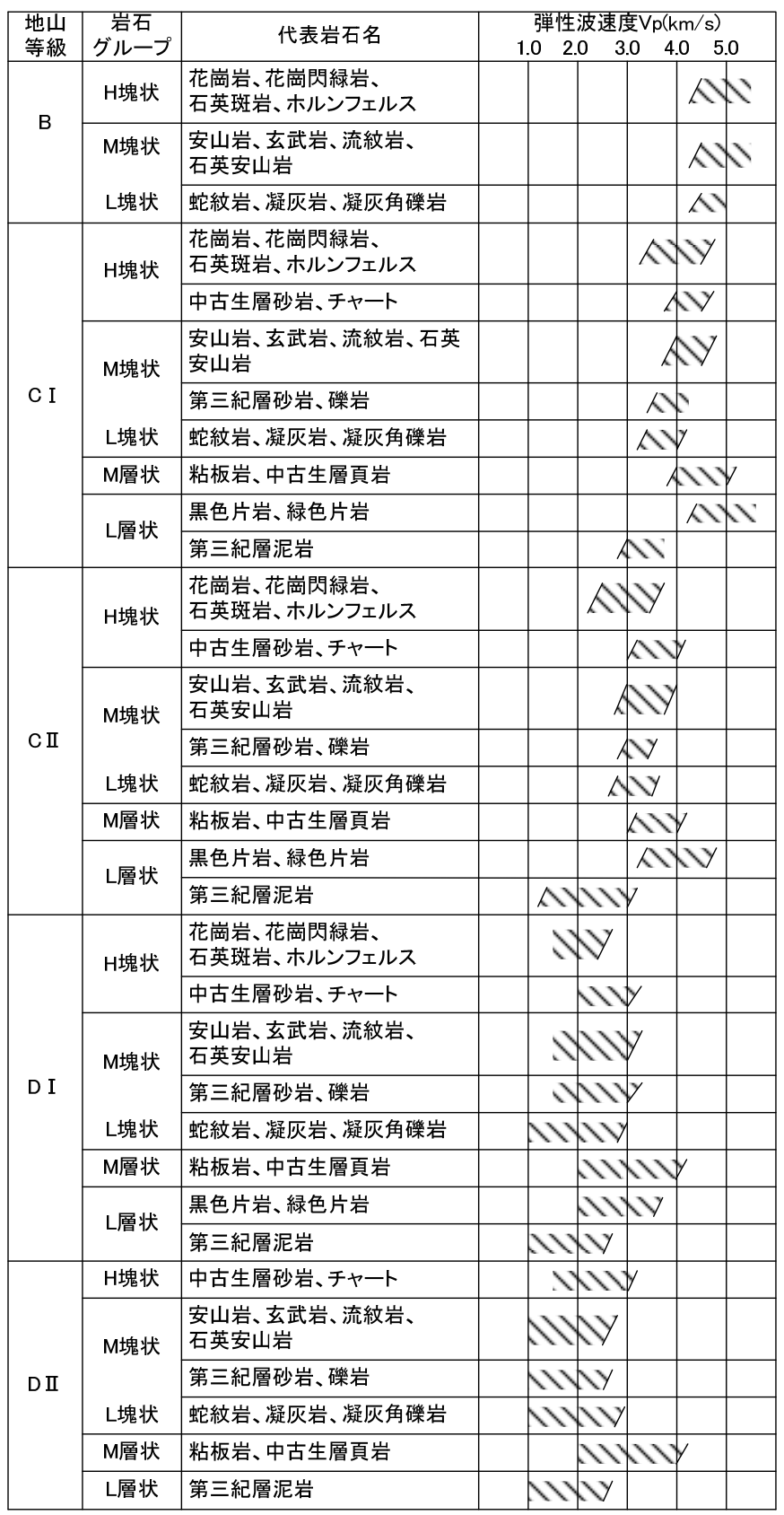

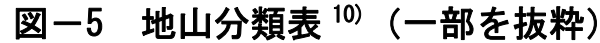

上面における弾性波速度より遅い速度が分布するも のとし, 最下層上面の弾性波速度で最も速い值であ る $4.8 \mathrm{~km} / \mathrm{s}$ より遅いと考える。一方，図一5 より第三 紀層泥岩の弾性波速度は $1.0 \sim 4.0 \mathrm{~km} / \mathrm{s}$ となっている。 なお， $4.0 \mathrm{~km} / \mathrm{s}$ 以上であっても C I 地山と判定される。 このようなことから, 最下層以深の弾性波速度は地 山分類表による速度区分をもとに $1.0 \sim 4.0 \mathrm{~km} / \mathrm{s}$ が分 布すると仮定する。

地山等級の判定は，トンネル掘削位置において $10 \mathrm{~m}$ を単位区間として行う。本トンネルの全長は 
1,696m であるので，単位区間数は 170 となる. 図一2 に示したようにトンネルのほとんどの区間は最下層 以深に位置するため，全ての区間の弾性波速度は 1.0 $\sim 4.0 \mathrm{~km} / \mathrm{s}$ の不確実性を有するものとして単純化し, 各単位区間において以下の方法により地山等級の判 定を行う。

- $1.0 \sim 4.0 \mathrm{~km} / \mathrm{s}$ の一様乱数を発生させて弾性波速度 の不確実性を与える。ここで，発生させる乱数の 数は 10,000 個とする.

- 10,000 個の弾性波速度それぞれについて地山等級 の判定を行う。ここで，図ー5に示したように第 三紀層泥岩における弾性波速度区分は, C I 地山 で $2.8 \sim 4.0 \mathrm{~km} / \mathrm{s}$ ，C II 地山で $1.2 \sim 3.2 \mathrm{~km} / \mathrm{s} ，$ D I 地 山と D II 地山で 1.0〜 2.6km/s となる. D I 地山と D II 地山はまとめて D 地山として扱うものとする. このとき, 弾性波速度区分は C I 地山と C II 地山 で $2.8 \sim 3.2 \mathrm{~km} / \mathrm{s}$ ，C II 地山と D 地山で $1.2 \sim 2.6$ $\mathrm{km} / \mathrm{s}$ で重なる。このような場合は，0１の一様乱 数を発生させ， 0.5 以上であれば良好側の地山等 級（C I 地山と C II 地山であれば C I 地山，C II 地 山と D 地山であれば C II 地山）を選択し，0.5 未 満であれば不良側の地山等級を選択する。上記に より 10,000 個の弾性波速度が得られていることか ら，10,000 個の地山等級のデータが得られる.

- 判定された地山等級に対して, 表一1に示守掘削 単価を適用する。ここで，単位区間は $10 \mathrm{~m}$ なので， 単位区間の掘削コストは表ー1 に示した掘削単価 の 10 倍となる.こうして得られた 10,000 個の掘 削コストデータを降順に並べる.

単位区間ごとに得られる降順に並んだ 10,000 個の 掘削コストデータに対して, 図ー6 に示すように, 上位から順にトンネル全長（170 区間）の掘削コス トの総和を計算する。これにより，降順に並んだ 10,000 個のトンネル掘削コストが得られる. こうし て得られる掘削コストに対して, 横軸に掘削コスト, 縦軸に「降順の順位/データ数」の值をとり, デー タをプロットすれば，図ー7 に示す縦軸を超過確率 とするリスクカーブが得られる。ここで, 青線が得 られた掘削コストのカーブであり, 赤線は施工実績 における支保工パターンをもとに表一 1 より算出し

\section{表ー1 2 車線道路トンネルに対する地山等級区分の} 掘削単価 (NATM 積算研究会 ${ }^{11)} も と に$ 作成)

\begin{tabular}{|c|c|}
\hline 地山等級区分 & 掘削単価 $($ 円 $/ \mathrm{m})$ \\
\hline B & 620,000 \\
\hline CI & 680,000 \\
\hline CII & 800,000 \\
\hline D & $1,280,000$ \\
\hline
\end{tabular}

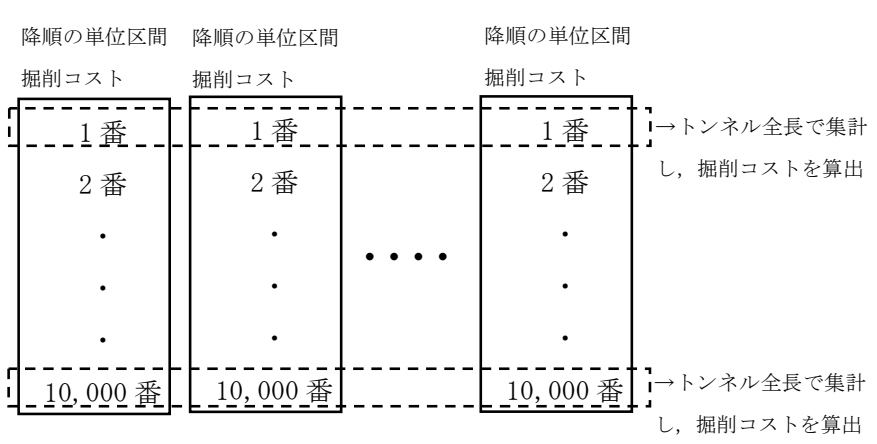

\section{図－6トンネル全長の掘削コストの算出方法}

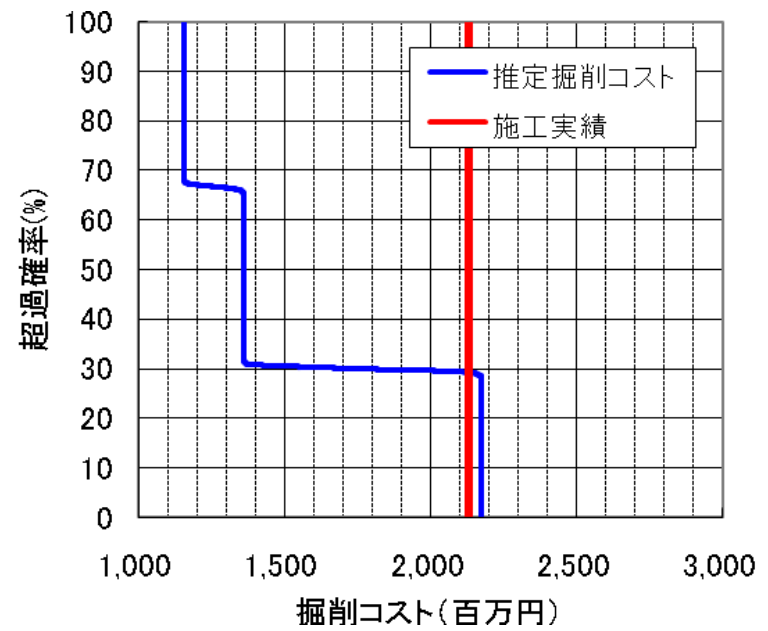

図－7地山分類表による地山評価におけるリスク カーブ

た掘削コストである．山岳トンネルにおいては，基 本的には地山等級に応じた支保工パターンが採用さ れるが，地山状況に応じて頻繁に支保工パターンを 変更することによるコスト増を回避するなどの理由 により，必ずしも実際の地山等級とは異なる支保工 パターンが採用される場合がある。したがって，こ こに示す施工実績は，実際の地山状況を推察する参 
考值である.

図ー7 に示寸ように, リスクカーブは 11.6 億円, 13.6 億円， 21.8 億円の 3 つに大きく区分される。 こ れは，それぞれトンネル全長の地山等級が全て C I 地山である場合の掘削コスト（11.6 億円），C II 地 山である場合の掘削コスト（13.6 億円），D 地山で ある場合の掘削コスト（21.8 億円）に一致する。こ れは，一様乱数を用いてトンネル掘削位置の弾性波 速度を与えたときの各地山等級の出現確率を反映し ており，トンネル地山の弾性波速度の分布を考慮し ていないことが理由として考えられる. リスクカー ブと施工実績との交点における超過確率は $30 \%$ であ り，岩種による弾性波速度のみで地質リスクを評価 した場合には，施工実績に示される地山状況が出現 する確率は，それほど低くない，すなわち，一般的 な第三紀層泥岩を想定した場合には，本トンネルの 地山状況は特殊な地山ではないといえる.

\section{4. 追加調查における地質リスクと施エ実績との 比較}

地山等級を判定する手法として，コア評価点によ る地山評価手法が提案されている ${ }^{12)}$ 。著者らは，一 連の研究 ${ }^{5) \sim 8)}$ においてコア評価点による地山評価手 法についても地質リスク評価手法を検討してきた。 ここでは，その手法を用いる.

\section{（1）コア評価点による地山評価手法}

トンネル切羽においては，切羽観測結果から地山 等級を判定する手法が開発されている（新切羽評価

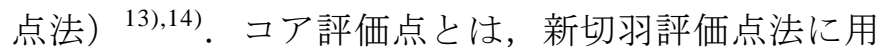
いられている評価項目と評価区分を参考に，ボーリ ングコアの圧縮強度, 風化変質, 割れ目の間隔, 割 れ目の状態について点数化し, 各点数を合計した点 数である. 湧水と水による劣化については, マイナ ス調整点として合計点から引く，本論文では，各評 価項目の評価区分における配点は, 文献 14 に示され る切羽評価点における配点表を用いる（表一2）。岩 石グループ 1 は塊状・硬質岩, 岩石グループ 2 は塊 状・中硬質岩之塊状・軟質岩, 岩石グループ 3 は層 状・硬質岩, 岩石グループ 4 は層状・中硬質岩と層 状・軟質岩である，岩石グループ 4 の代表的な岩石 は緑色片岩, 黒色片岩, 第三紀層泥岩であり, 本卜
表－2 コア評価点における評価区分と配点 ${ }^{14)}$

\begin{tabular}{|c|c|c|c|c|c|c|c|}
\hline \multicolumn{2}{|c|}{ 岩質/評価区分 評点 } & 1 & 2 & 3 & 4 & 5 & 6 \\
\hline \multirow{4}{*}{$\begin{array}{l}\text { 岩 } \\
\text { 石 } \\
\text { ル } \\
\text { I } \\
\text { プ } \\
1\end{array}$} & 圧縮強度 & 40 & 32 & 24 & 16 & 8 & 0 \\
\hline & 風化変質 & 18 & 12 & 6 & 0 & - & - \\
\hline & 割れ目の間隔 & 16 & 12 & 8 & 4 & 0 & - \\
\hline & 割れ目の状態 & 26 & 19 & 13 & 6 & 0 & - \\
\hline \multirow{4}{*}{$\begin{array}{l}\text { 岩 } \\
\text { 名 } \\
\text { ル } \\
\text { । } \\
\text { プ } \\
2\end{array}$} & 圧縮強度 & 31 & 25 & 19 & 13 & 6 & 0 \\
\hline & 風化変質 & 22 & 15 & 7 & 0 & - & - \\
\hline & 割れ目の間隔 & 20 & 15 & 10 & 5 & 0 & - \\
\hline & 割れ目の状態 & 27 & 20 & 13 & 7 & 0 & - \\
\hline \multirow{4}{*}{$\begin{array}{l}\text { 岩 } \\
\text { 石 } \\
\text { ル } \\
\text { । } \\
\text { プ } \\
3\end{array}$} & 圧縮強度 & 32 & 26 & 19 & 13 & 6 & 0 \\
\hline & 風化変質 & 26 & 17 & 9 & 0 & - & - \\
\hline & 割れ目の間隔 & 14 & 10 & 7 & 3 & 0 & - \\
\hline & 割れ目の状態 & 28 & 21 & 14 & 7 & 0 & - \\
\hline \multirow{4}{*}{$\begin{array}{l}\text { 岩 } \\
\text { グ } \\
\text { ル } \\
\text { I } \\
4 \\
4\end{array}$} & 圧縮強度 & 37 & 30 & 22 & 15 & 7 & 0 \\
\hline & 風化変質 & 15 & 10 & 5 & 0 & - & - \\
\hline & 割れ目の間隔 & 21 & 15 & 10 & 5 & 0 & - \\
\hline & 割れ目の状態 & 27 & 20 & 14 & 7 & 0 & - \\
\hline
\end{tabular}

\begin{tabular}{|c|c|c|c|c|c|}
\hline \multicolumn{2}{|c|}{} & \multicolumn{4}{|c|}{ 湧水 } \\
\cline { 2 - 6 } \multicolumn{2}{|c|}{} & 1 & 2 & 3 & 4 \\
\hline \multirow{4}{*}{ 劣 } & 1 & 0 & 0 & -5 & -10 \\
\cline { 2 - 6 } & 2 & 0 & -5 & -7 & -10 \\
\cline { 2 - 6 } & 3 & -5 & -7 & -10 & -15 \\
\cline { 2 - 6 } & 4 & -7 & -10 & -15 & -20 \\
\hline
\end{tabular}

ンネル地山は主な地質である古第三紀泥岩のみを考 えれば岩石グループ 4 亿該当する.

コア評価点による地山等級判定の流れを図ー8に示 す.ボーリングコアの観察などから得られるコア評 価点と，コアを採取したボーリング孔で実施される 速度検層などにより得られる弾性波速度をもとに， 弾性波速度とコア評価点との相関式を求める。この 相関式をもとに，トンネル掘削位置における弾性波 速度から，トンネル掘削位置におけるコア評価点を 算出する。ここで，コア評価点と切羽評価点はほぼ 一致すると仮定し，新切羽評価点法で用いられてい る切羽評価点と地山等級との関係を用いて，コア評 


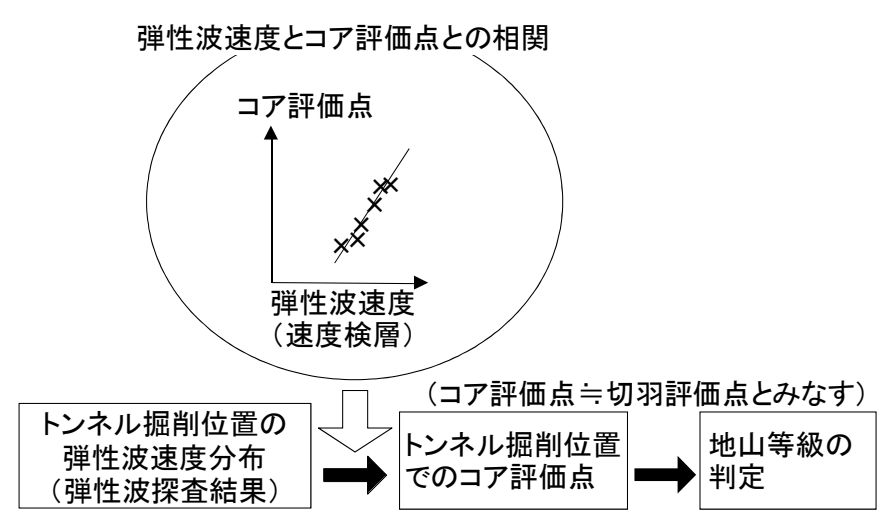

図－8 コア評価点による地山等級の判定の流れ

価点から地山等級の判定を行う。

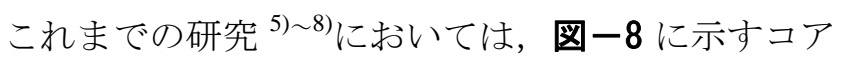
評価点による地山等級の判定における不確実性の要 因として，トンネル掘削位置における弾性波速度の 不確実性, 弾性波速度とコア評価点との相関におけ る不確実性，コア評価点に基づく地山等級の判定に おける不確実性を考慮してきた。そこで, 本論文に おいても，これらの不確実性を考慮する。以下に， それぞれの不確実性の評価方法について述べる.

\section{（1）高精度弾性波探查による弾性波速度の不確実性}

弾性波探查により得られる弾性波速度の不確実性 を評価する手法は，これまでのところ確立されてい ない，そこで，本論文では，高精度弾性波探査によ る弾性波速度を平均值とし, 平均值の $10 \%$ よび $20 \%$ を標準偏差とする正規分布乱数で弾性波速度の 不確実性を仮想的に与える.

図ー4 に示したように, 高精度弾性波探査により得 られるトンネル掘削位置における弾性波速度は概ね $4.0 \mathrm{~km} / \mathrm{s}$ であることから，弾性波速度を $4.0 \mathrm{~km} / \mathrm{s}$ とし， 弾性波速度の $10 \%$ を標準偏差とした場合，20\%を標 準偏差とした場合の確率密度分布を図一9に示寸. 弾 性波速度の分布幅は，10\%を標準偏差とした場合は 概ね $2.8 〜 5.2 \mathrm{~km} / \mathrm{s} ， 20 \%$ を標準偏差とした場合は 2.0 $\sim 6.0 \mathrm{~km} / \mathrm{s}$ となる. 地山分類表における $\mathrm{L}$ 層状第三紀 層泥岩の弾性波速度区分は $1.0 \sim 4.0 \mathrm{~km} / \mathrm{s}$ であり，こ れと比べると地山分類表に示される弾性波速度区分 の上限を中心に大きな不確実性を与えていることが わかる。

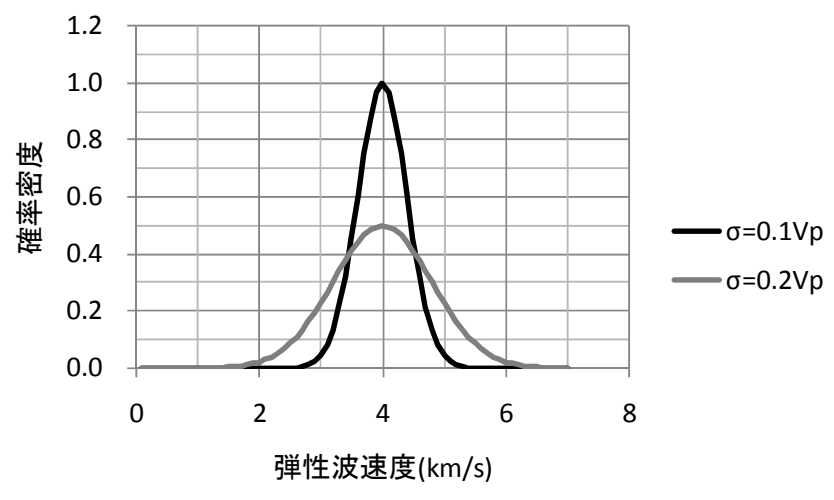

図－9 弾性波速度の平均値 $(V p)$ を $4.0 \mathrm{~km} / \mathrm{s}$ とし，標 準偏差を弾性波速度の $10 \%(\sigma=0.1 \mathrm{Vp})$ および $20 \%$ $(\sigma=0.2 V p)$ としたときの確率密度分布
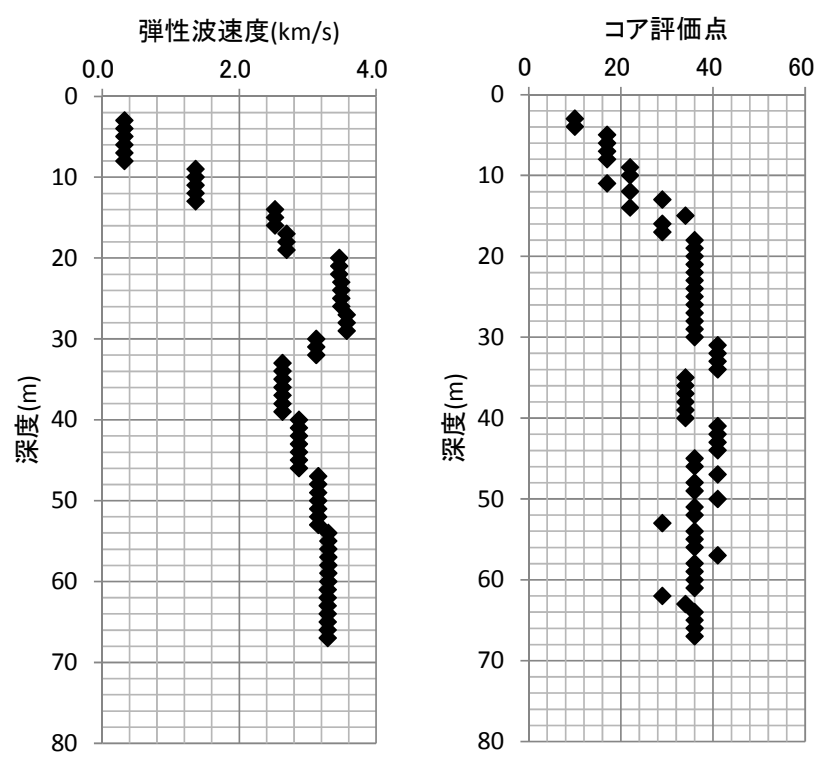

図ー10 TB-1 孔の弾性波速度とコア評価点

トンネル掘削位置における弾性波速度は，単位区 間を $10 \mathrm{~m}$ とし，単位区間ごとに高精度弾性波探查結 果を平均值 $\mathrm{V}_{\mathrm{p}}$ とし, 標準偏差 $\sigma=0.1 \mathrm{~V}_{\mathrm{p}}$ および $\sigma$ $=0.2 V_{\mathrm{p}}$ とする正規分布乱数を 10,000 個発生させて弾 性波速度を与える。

\section{（2）弾性波速度とコア評価点の相関における不確実性}

TB-1 孔では孔壁保護のためトンネル掘削深度付近 を除き保護管が挿入された。このため, 速度検層は 実施されていない。そこで, 本論文では, 速度検層 の代わりに高精度弾性波探査による TB-1 孔沿いにお ける弾性波速度を用いる。

図ー10 に TB-1 孔沿いにおける高精度弾性波探查 


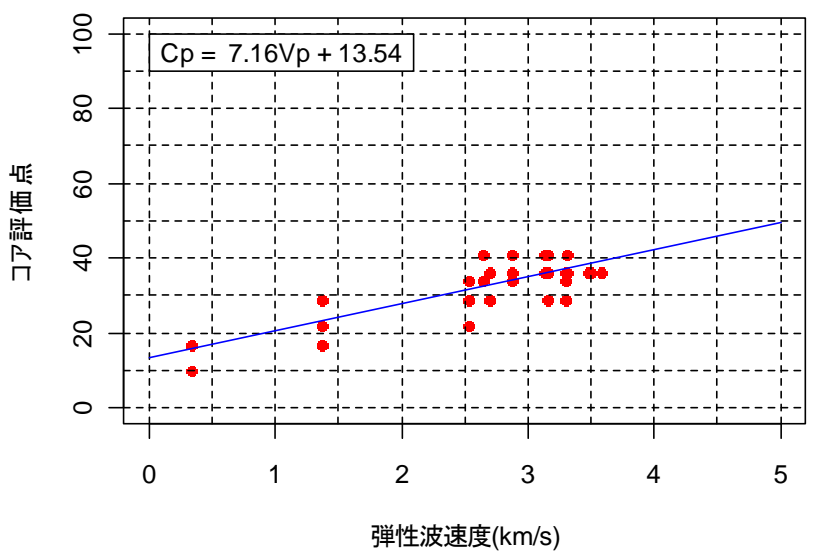

図-11 弾性波速度（高精度弾性波探查）とコア評 価点との比較

表-3 コア評価点と地山等級との関係 (文献 14 の切 羽評価点と支保パターンの目安をもとに作成）

\begin{tabular}{|c|c|}
\hline 地山等級 & コア評価点 \\
\hline B & 65 以上 \\
\hline C I & $55 \sim 70$ \\
\hline C II & $35 \sim 60$ \\
\hline D & 40 以下 \\
\hline
\end{tabular}

による弾性波速度とコア評価点を示す。データ数は 65 である. 図ー10 に示した同一深度における弾性波 速度とコア評価点との関係を図ー11 に示寸。このデ ータから相関式を近似直線で与える。近似直線式及 び近似直線式で求められるコア評価点と実際のコア 評価点とのばらつきを示す標準偏差 $\sigma$ は式(1)となる.

$$
C_{p}=7.16 \cdot V_{p}+13.5, \quad \sigma=3.90
$$

ここで， $C_{p}$ はコア評価点， $V_{p}$ は弾性波速度 $(\mathrm{km} / \mathrm{s})$ で ある。この式における不確実性は, 式(1)で求められ るコア評価点 $C_{p}$ を平均值とし, 式(1)の $\sigma$ を標準偏差 とする正規分布乱数を 1 つ発生させて与える. トン ネル掘削位置において単位区間ごとに 10,000 個の弾 性波速度データを与えていることから，式(1)により 単位区間ごとに 10,000 個のコア評価点が得られる。

なお，ここで示した弾性波速度とコア評価点との 関係は TB-1 孔での関係であり, 他のボーリング孔の データを追加されるなど, データが異なれば相関式
は変わることに留意する必要がある.

\section{（3）コア評価点による地山等級判定における不確実性}

コア評価点による地山等級の判定は，コア評価点 と切羽評価点はほぼ等しいとみなし，文献 14 におい て切羽評価点と地山等級（文献 14 では支保選定とし ている）の目安として示される関係を用いる。表一3 にコア評価点と地山等級との関係を示す. 文献 14 に おける B-a を B, C I -a を C I , C II-a と C II -b を C II, D I -a と D I -bを D としている. B 地山と C I 地山では 65〜70 点, C I 地山と C II 地山では 55〜 60 点, CII 地山と D 地山では 35〜40 点で重なる. これ により，コア評価点が同じでも異なる地山等級に判 定されうる。これがコア評価点による地山等級の判 定における不確実性とみな寸。そこで，地山等級に 対してコア評価点が重なる場合には，地山分類表の 場合と同様に $0 \sim 1$ の一様乱数を発生させ, 0.5 以上 であれば良好側の地山等級, 0.5 未満であれば不良側 の地山等級を選択する。なお，トンネル掘削位置に おいて単位区間ごとに 10,000 個のコア評価点データ が得られることから，単位区間ごとに 10,000 個の地 山等級データが得られる.

\section{（4）地質リスク評価結果}

単位区間ごとに得られる 10,000 個の地山等級デー 夕に対して, 表一 1 に示した掘削単価を適用し，掘削 コストを算出する。そして，事前調査における検討 と同様に，図一6に示したように単位区間ごとに掘削 コストを降順に並べ替え, 上位から順にトンネル全 長の総和をとることにより，トンネル掘削コストを 算出する。こうして得られた 10,000 個のトンネル全 長の掘削コストデータから，図ー7 と同様に横軸を掘 削コスト，縦軸を超過確率とするリスクカーブが得 られる。得られたリスクカーブを図ー12 に示す。青 線が高精度弾性波探査による弾性波速度の $10 \%$ を標 準偏差として与えたときのリスクカーブ（ $\left.=0.1 \mathrm{~V}_{\mathrm{p}}\right)$ ，緑線が $20 \%$ を標準偏差として与えたとき のリスクカーブ $\left(\sigma=0.2 \mathrm{~V}_{\mathrm{p}}\right)$ である. 施工実績とリ スクカーブとの交点における超過確率は， $\sigma=0.1 \mathrm{~V}_{\mathrm{p}}$ の場合で約 $7 \%$, また， $\sigma=0.2 \mathrm{~V}_{\mathrm{p}}$ の場合で約 $14 \%$ で ある. TB-1 孔のボーリング調査, 高精度弾性波探査 により地盤情報が追加されたにもかかわらず，リス 


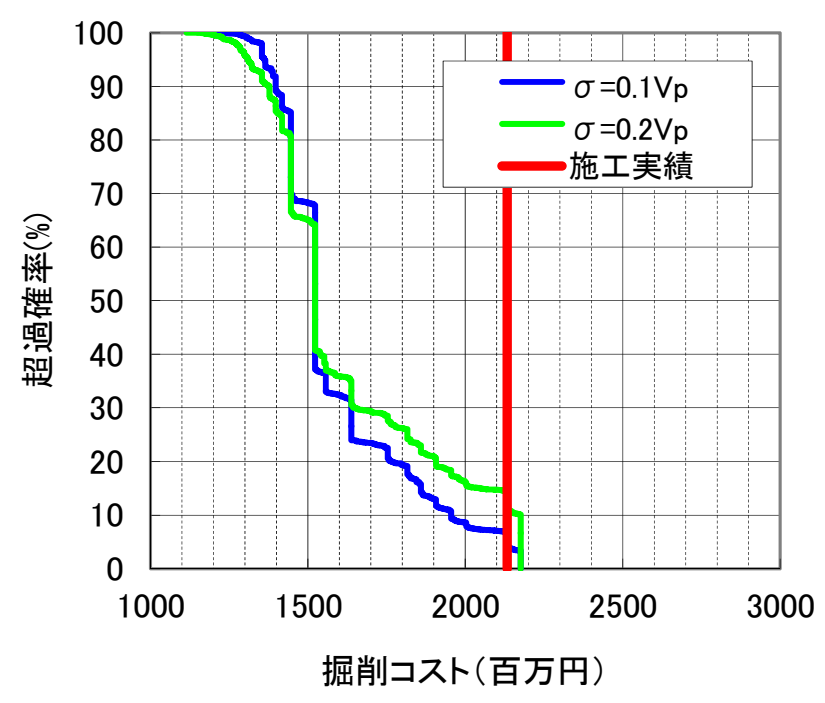

図ー12 コア評価点による地山評価におけるリスク カーブ

クカーブにおいて施工実績が位置する超過確率は, 事前調査における地質リスクより低い結果となって いる，どこまでのリスクに備えるかは，リスクを負 担する者の置かれた状況による，仮に超過確率 $10 \%$ までのリスクに備えることを選択した場合, 施工実 績に示される地山状況は, 事前調査では考慮される が，追加調査では考慮されなくなる.

このような結果となった原因として，以下のこと が考えられる。式(1)により弾性波速度からコア評価 点を計算すると, 図一11に示したように弾性波速度 が $3.7 \mathrm{~km} / \mathrm{s}$ 以上の場合にはコア評価点 40 点以上とな り，その結果，表一3 に基づき CII 地山と判定される. これに対して高精度弾性波探査の結果では, 図ー4に 示したようにトンネル掘削位置における弾性波速度 は概ね $3.9 \mathrm{~km} / \mathrm{s}$ 以上である。したがって, 弾性波速度 の不確実性を考慮しても，平均的には C II 地山と判 定される. 表一 3 に示したように, コア評価点が 35 点以下であれば D 地山と判定されるが，式(1)により コア評価点が 35 点となる弾性波速度は $3.0 \mathrm{~km} / \mathrm{s}$ とな る. コア評価点が 35〜40 点のときは $1 / 2$ の確率で D 地山と判定されるが，このときの弾性波速度は 3.0〜 $3.7 \mathrm{~km} / \mathrm{s}$ となる. 図一 9 から推察されるように, 弾性 波速度が $3.0 \mathrm{~km} / \mathrm{s}$ 以下となる確率は低く，また，3.0 〜3.7km/s においては $1 / 2$ の確率で D 地山と判定され ることから，D 地山がほとんど現れない結果となり，
リスクカーブにおいて施工実績で示される地山状況 （ほとんどが D 地山）が出現する確率は低い結果に なったものと考えられる.

\section{（5）コア評価点の不確実性を考慮した地質リスク}

コア評価点は, ボーリングコアの圧縮強度, 風化 変質, 割れ目の間隔, 割れ目の状態について点数化 する.ここで, 各評価項目の配点は, 表一2 に示した とおりである。配点は離散值をとり, 配点間の差も 大きいものがある，例えば，図ー10 に示す TB-1 孔 においてコア評価点が 40 点を超える深度 $31 \mathrm{~m}$ のデー 夕を見ると, 圧縮強さ 7 点, 風化変質 15 点, 割れ目 の間隔 0 点, 割れ目の状態 14 点で, 合計点であるコ ア評価点は 41 点であった。この評価点の場合, 表一 3 に示したコア評価点と地山等級との関係から C II 地 山と判定される。しかし，コア評価点は評価を行う 技術者の判断に基づくものであり，その判断には不 確実性を含んでいる。仮に，上記に示した深度 $31 \mathrm{~m}$ のデータについて, 風化変質の評価を表一2において 1 ランク下げて 10 点とした場合には，コア評価点は 36 点となり, 地山等級は $\mathrm{D}$ 地山と判定される.この ようなことから，コア評価点の不確実性を考慮した 地山評価を試みる.

ここで,コアの状態は各評価区分の中間的な状態 にあり，技術者がコアで判定した評点は 1 ランク不 良側の評点も取り得るものと仮定する。このとき, コアで判定した評点と不良側の評点（表ー2 において 配点が小さくなる側の評点）が $1 / 2$ の確率で取り得る ものとする．ただし，コアで判定した評点が各評価 項目の最高点（圧縮強さであれば 6, 風化変質であれ ば 4, 割れ目の間隔及び割れ目の状態であれば 5）の 場合は，コアで判定した評点を用いる。

図ー11 に示した 65 点のデータそれぞれについて, 0〜1 の一様乱数を 10,000 個発生させ, 0.5 以上であ れば技術者が判定した評点， 0.5 未満であれば，その 評点より 1 ランク不良側の評点をとるものとする. こうして得られた評点に対して表－2の配点表により 点数化し, その合計点でコア評価点を求める. なお, 全ての評価項目において $1 / 2$ の確率で不良側の評点を 与える方法は, 不良地山側に極端に偏った与え方で あることに留意する必要がある.

図ー13に乱数により発生させたコア評価点と弾性 


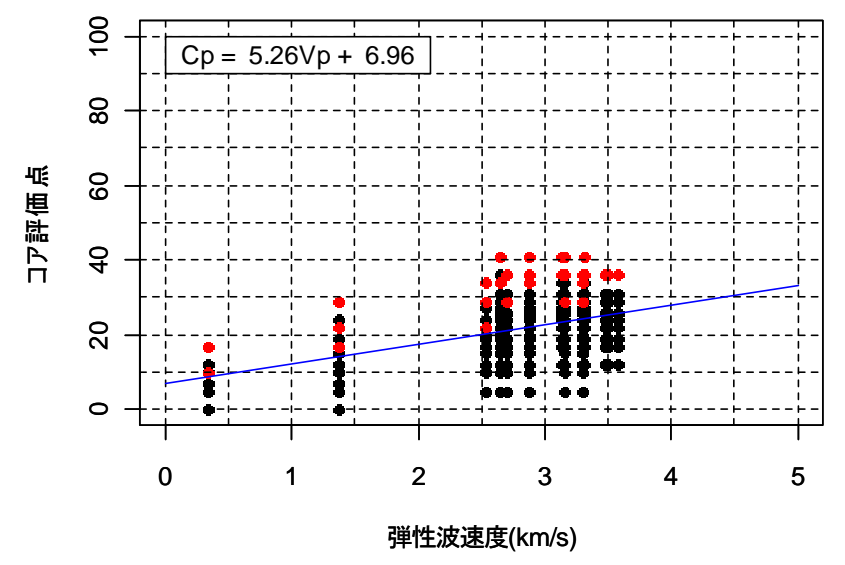

図-13 弾性波速度（高精度弾性波探査）とばらつ きを与えたときのコア評価点

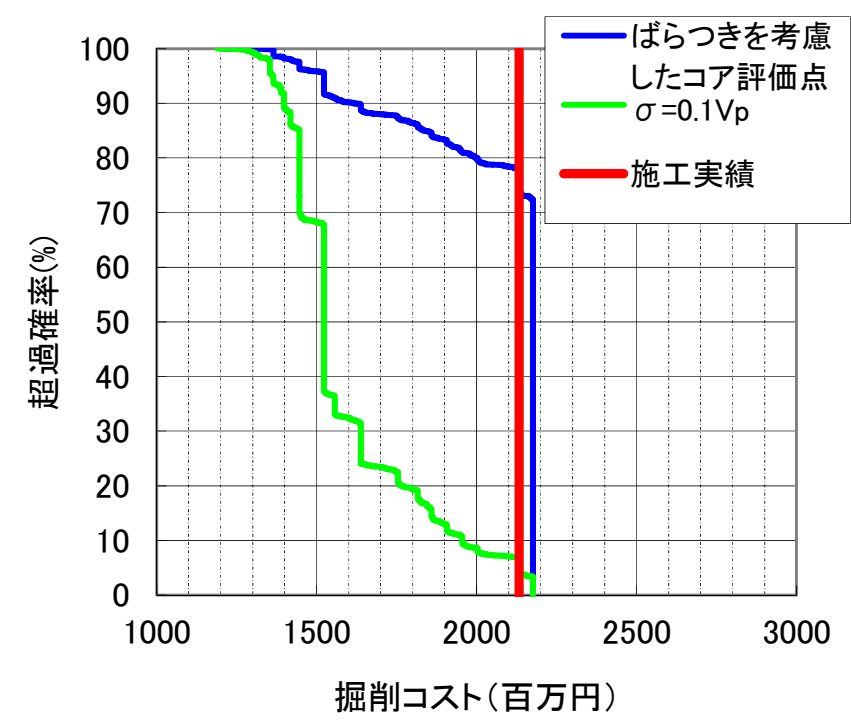

図ー14 コア評価点と弾性波速度にばらつきを与え たときのリスクカーブ

波速度との関係を示す. 黒点が乱数により発生させ たコア評価点，赤点が図ー11 に示した技術者が判断 したコア評価点である. 黒点で示すデータから求め た近似直線及び近似直線から求められるコア評価点 と図ー13 に示したデータのばらつきを示寸標準偏差 を式(2)に示す.

$$
C_{p}=5.26 \cdot V_{p}+6.96, \quad \sigma=7.93
$$

ここで， $C_{p}$ はコア評価点， $V_{p}$ は弾性波速度 $(\mathrm{km} / \mathrm{s})$, $\sigma$ は標準偏差である.

図ー14 にリスクカーブを示す. 緑線は, 弾性波速
度 $\mathrm{V}_{\mathrm{p}}$ に $\sigma=0.1 \mathrm{~V}_{\mathrm{p}}$ のばらつきを与えたときのリスクカ ーブ（図ー12 における $\sigma=0.1 \mathrm{Vp}$ のカーブと同じ）で ある.リスクカーブが施工実績と交差するときの超 過確率は約 78\%であり, 事前調查のリスクカーブに おける確率より高い。これは，式(2)よりコア評価点 が 40 点となる弾性波速度は $6.3 \mathrm{~km} / \mathrm{s}$ であるのに対し， 図ー4に示した高精度弾性波探査によるトンネル掘削 位置における弾性波速度は $4.2 \mathrm{~km} / \mathrm{s}$ 以下であることか ら，弾性波速度の不確実性を考慮しても，ほとんど が D 地山と判定されることによると考えられる。

ここで示したコア評価点の不確実性の与え方は, 前述のように, 不良地山側に極端に偏った与え方で ある。ただ，コア評価点の不確実性をどのように与 えるかという問題はあるものの，コア評価点そのも のの不確実性を考慮することで, 施工実績に示され る地山状況をより適切に捉えられる可能性がある.

\section{6. まとめ}

本論文では，事前調查において予見されなかった 不良地山に遭遇し, 施工段階において追加調査を実 施した事例を用いて地質リスクの検討を行った。こ のような事例においては, 施工実績で示される地山 状況が出現する確率は, 事前調査における地質リス クでは低く, 追加調査における地質リスクでは高い ことを予想した。 しかし, 事前調査における地質リ スク評価では, 地山分類表を用いて岩種のみで評価 （ここでは第三紀層泥岩のみで評価）した結果，リ スクカーブにおいて施工実績が位置する超過確率は 約 30\%となり, 決して低い值ではなかった。一方, 追加調查においては，ボーリング調査とボーリング 孔を利用した高精度弾性波探査を実施することによ り，事前調查における屈折法弾性波探查により得ら れた最下層以深の地山性状と弾性波速度に関する情 報が追加された。本論文では，これらの情報を利用 し,コア評価点により地山等級の判定を行った。た だ，コア評価点の不確実性を考慮しない場合には, リスクカーブにおいて施工実績が位置する超過確率 は事前調查の場合より低い值となった。これにより， 単に地盤情報を追加すれば施工実績で示される地山 状況を適切に捉えられるようになるわけではないこ とがわかった。また，コア評価点の不確実性を考慮 した場合には, リスクカーブにおいて施工実績が位 
置する超過確率は約 $78 \%$ となり, 事前調査の場合よ り大きい值となった．本論文におけるコア評価点の 不確実性は，仮想的に不良地山側に極端に偏らせて 与えたが，適切にコア評価点の不確実性を与えるこ とにより, 施工実績に示される地山状況を適切に捉 えられる可能性があることがわかった。したがって，

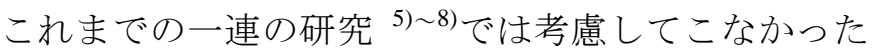
コア評価点そのものの不確実性を考慮する必要があ ることがわかった。

これまでの地盤調査では, 得られる地盤情報に不 確実性（あいまいさ）が存在していても，いわゆる

「技術者の判断」により地盤情報を確定的に決めて きた．このことにより，予見されない地山が出現す る確率を過小評価する可能性があることがわかった。 本論文においては，コア評価点の不確実性を考慮し ない場合がこれに該当する。「技術者の判断」の部 分をどのように確率的に扱うかという問題はあるが， 地質リスク評価においては，このような問題も含め て，不確実性を積極的に評価することが重要であり， しかも適切に評価することが必要であると考える.

\section{【参考文献】}

1) 飯酒盃久夫：トンネル地質の予測が当たらない 諸因子について、日本灾用地質学会シンポジウ 么予稿集、pp.52-60、2001.

2) 鈴木守・冨田宏夫：トンネル地質調查の性格 と問題点（2），トンネルと地下，1993.10.

3）中川浩二・保岡哲治・北村晴夫・三木茂・藤 本睦・木村恒雄 : トンネル事前設計における 地質調査の問題点とその評価に関する研究, 土木学会論文集, No.658/VI-48, pp.33-43, 2000.

4）地質リスク学会・（社）全国地質調查業協会連 合会(2010)：地質リスクマネジメント入門, ohmsha.

5）長谷川信介・大津宏康：トンネル事前調査にお ける地山評価の不確実性評価に関寸る検討，建
設マネジメント研究論文集，Vol.13，pp.145152, 2006.

6) 長谷川信介・大津宏康・坂井一雄 : 山岳トンネ ル調査における地盤リスク評価の試み，建設マ ネジメント研究論文集, Vol.14, pp.45-54, 2007.

7) 大津宏康 - 坂井一雄 - 長谷川信介 : 屈折法弾性 波探査を用いた山岳トンネルにおける地山区分 推定手法に関する研究, 材料, 日本材料学会, Vol.56, No.9, pp.820-827, 2007.

8）酒井悠・大津宏康・長谷川信介：地盤リスク解 析手法を用いた山岳トンネル地質調査の価值評 価に関する研究，土木学会論文集 F，Vol.65, No.3, pp.299-312, 2009.

9) 長谷川信介, 木村正樹, 杉田理, 村岡直 : 電気 探査とボーリング孔を利用した弾性波探査の併 用による地山評価精度の向上，第 32 回岩盤力 学シンポジウム, pp.257-262, 2003.

10) 日本道路公団：設計要領第三集トンネル(1)トン ネル本体工建設編、p.71、平成 9 年 10 月.

11) NATM 積算研究会編：NATM の施工と積算, （財）経済調查会，2006.

12）木村正樹, 杉田理, 大塚康範：評価点法を用 いた事前調査による地山評価と施工，土木学 会トンネル工学研究発表会論文・報告集, 第 11 巻, pp.87-92, 2001.

13）中田雅博 - 三谷浩二 - 八木弘 - 西玩郎 - 西村 和夫・中川浩二 : 観察記録の分析に基づく新 しいトンネル切羽評価システムの提案，土木 学会論文集，No.623/VI-43，pp.131-141，1999.

14）赤木渉 - 佐野理 - 進士正人 - 西环郎 - 中川浩 二：山岳トンネル施工支援のための切羽評価 法の適用性に関寸る研究, 土木学会論文集, No.686/VI-52, pp.121-134, 2001. 


\title{
Consideration from a geological risk in a geological survey of mountain tunnel
}

\author{
By Nobusuke HASEGAWA, Hiroyasu OHTSU
}

In mountain tunnel construction project, ground condition expected in a preliminary survey and a real condition cause often large deviations. As the result, the large increase of construction cost occurs after the start of excavation. One of the causes of such deviations is the uncertainty of ground information in a preliminary survey. Then, we have studied on the evaluation technique for the uncertainty of ground information and the risk in tunnel digging cost fluctuation caused by the uncertainty (the following, geological risk). In the past study, we paid our attention to the quantity of deviations with an expected digging cost considering the uncertainty and a real cost. However, in geological risk management, it is important to consider the situation that occurs a significant loss when actualized, too. Therefore, conducting a case study in a tunnel that carried out an additional survey because a bad ground condition which was not foreseen in a preliminary survey appeared, we studied the geological risk in the preliminary and the additional survey, and compared with construction cost and geological risk. We expected that the probability that the real cost appeared on the risk curve in the additional survey would be higher than the one in the preliminary survey. However, the probability in the additional survey became lower than the one in the preliminary survey when the ground information was added without evaluating uncertainty of ground information appropriately. As the result, we found that it was important to add geological information which is evaluated appropriately, instead of simply adding geological information. 